\title{
Author Correction: ARMADILLO REPEAT ONLY proteins confine Rho GTPase signalling to polar growth sites
}

Ivan Kulich, Frank Vogler, Andrea Bleckmann (D), Philipp Cyprys, Maria Lindemeier, Ingrid Fuchs, Laura Krassini, Thomas Schubert, Jens Steinbrenner (1), Jim Beynon, Pascal Falter-Braun (B), Gernot Längst (1), Thomas Dresselhaus (1) and Stefanie Sprunck (iD)

Correction to: Nature Plants https://doi.org/10.1038/s41477-020-00781-1, published online 5 October 2020.

In the version of this Article originally published, one affiliation of the author Pascal Falter-Braun was mistakenly omitted; they should have also been affiliated with the Department of Plant Systems Biology, Center of Life and Food Sciences Weihenstephan, Technische Universität München. This error has now been corrected.

Published online: 6 January 2021

https://doi.org/10.1038/s41477-020-00841-6

(C) The Author(s), under exclusive licence to Springer Nature Limited 2021 